Original Research Paper

\title{
Pembelajaran Kompos dan Proses Pengomposan Limbah Kulit Singkong Metode Takakura Modifikasi Kepada Ibu Rumah Tangga Desa Narmada Kabupaten Lombok Barat
}

\author{
Lolita Endang Susilowati ${ }^{1 *}$, Zaenal Arifin ${ }^{1}$, Mahrup $^{1}$, Umminingsih $^{2}$ \\ ${ }^{1}$ Jurusan Ilmu Tanah, Fakultas Pertanian, Universitas Mataram, Mataram, Indonesia; \\ ${ }^{2}$ Mitra PKM, Kelompok PaManSam, Desa Narmada, Kabupaten Lombok Barat
}

https://doi.org/10.29303/jpmpi.v3i2.1403

Sitasi: Susilowati, L. E., Arifin, Z., Mahrup \& Umminingsih. (2022). Pembelajaran Kompos dan Proses Pengomposan Limbah Kulit Singkong Metode Takakura Modifikasi Kepada Ibu Rumah Tangga Desa Narmada Kabupaten Lombok Barat. Jurnal Pengabdian Magister Pendidikan IPA, 5(1)

\author{
Article history \\ Received: 11 Januari 2022 \\ Revised: 11 Februari 2022 \\ Accepted: 27 Februari 2022 \\ *Corresponding Author: Lolita \\ Endang Susilowati, Jurusan \\ Ilmu Tanah, Fakultas \\ Pertanian, Universitas \\ Mataram, Mataram, Indonesia; \\ Email: \\ lolitaabas37@unram.ac.id
}

\begin{abstract}
Limbah kulit singkong dengan sejumlah kandungan senyawa organik yang ada di dalamnya menjadikan limbah organik ini masih memiliki potensi untuk diolah menjadi produk turunannya yang mempunyai nilai ekonomis. Salah satu produk turunannya adalah mengolah limbah kulit singkong menjadi kompos yang bermanfaat untuk menopang kesuburan tanah. Kegiatan pengabdian ini bertujuan (1) memberikan pengayaan pengetahuan tentang kompos, proses pengomposan dan manfaat kompos untuk peningkatan produktivitas tanaman; (2) memberikan bimtek pembuatan mikroba pengurai bahan organik MOL dari bonggol pisang dan proses pengomposan limbah kulit singkong dengan metode Takakura modifikasi. Kegiatan ini menerapkan pendekatan partisipatif pada setiap tahap kegiatan mulai dari tahap perencanaan, pelaksanaan, dan evaluasi kegiatan. Peningkatkan pengetahuan khalayak sasaran tentang pupuk kompos dan proses pembuatannya diberikan melalui kegiatan penyuluhan dengan metode ceramah, diskusi dan tanya jawab. Penguasaan cara pembuatan MOL dan proses pengomposan dengan metode Takakura modifikasi disampaikan dengan praktek langsung. Hasil kegiatan pengabdian adalah sebagai berikut: (1) kegiatan ini mendapat respon positif dan terjadi kerjasama yang baik antara khalayak sasaran dan pelaksana pengabdian; (2) khalayak sasaran mendapatkan ilmu pengetahuan tentang kompos, teknik pembuatan kompos dan manfaat kompos di bidang budidaya tanaman; (3) khalayak sasaran termotivasi untuk mengolah limbah kulit singkong menjadi kompos; (4) khalayak sasaran menguasai cara membuat MOL berbahan baku bonggol pisang.
\end{abstract}

Keywords: Kompos; Kulit singkong; MOL.

\section{Pendahuluan}

Di Desa Narmada terdapat beberapa industri rumah tangga yang mengolah singkong menjadi kripik singkong. Usaha produksi kripik singkong di sekitar lokasi itu menghasilkan limbah padat berupa kulit singkong dan potongan ujung buah singkong yang tidak termanfaatkan dan diperkirakan banyaknya mencapai 3-5 $\mathrm{kg}$ per hari per rumah tangga (hasil wawancara). Limbah singkong ini tidak dikelola secara optimal, mereka membuang begitu saja di lahan terbuka, di sekitar pekarangan rumah atau, di bawah pohon pisang. Proses pembusukan timbunan limbah kulit singkong ini sangat mengganggu lingkungan karena memunculkan bau yang tidak sedap, berpotensi melepas gas metan sehingga mencemari udara dan menjadi sarang tumbuhnya organisme pengganggu tanaman ataupun kesehatan manusia (Obueh \& 
Odesiri-Eruteyan, 2016). Sementara jika limbah kulit singkong ini diolah secara tepat guna menjadi produk turunan limbah kulit singkong yang mempunyai nilai ekonomi akan membawa berkah bagi kehidupan.

Sebagai limbah organik, limbah kulit singkong dapat diolah menjadi sumber pakan ternak (Bui et al., 2018), biofuel (Elemike et al., 2015), dan pupuk kompos (Fadli, 2020; Oghenejoboh et al., 2021). Diantara produk turunan limbah kulit singkong yang paling mudah prosesnya adalah mengolah limbah kulit singkong menjadi pupuk kompos. Limbah kulit singkong potensial untuk dijadikan kompos karena limbah kulit singkong masih mengandung sejumlah hara yang dibutuhkan oleh tanaman (Oghenejoboh et al., 2021). Fitriani \& Ciptandi, (2017) melaporkan dalam 100 gram limbah kulit singkong mengandung protein 8,11 gram, serat kasar 15,20 gram, pektin 0,22 gram, lemak 1,29 gram, kalsium 0,63 gram.

Proses pengolahan menjadi pupuk dilakukan dengan proses pengomposan secara aerob. Proses pengomposan aerob adalah proses di mana bahan organik mengalami penguraian secara biologis, khususnya oleh mikroba aerob yang memanfaatkan bahan organik sebagai sumber energi (Djaja, 2008). Model pengomposan aerob untuk sekala rumah tangga yang telah dipopulerkan di lingkungan ibuibu rumah tangga adalah proses pengomposan metode Takakura (Dinas LKH, 2020). Proses pembuatan kompos Takakura sangat mudah, akan tetapi beberapa bahan dan perangkatnya harus dibeli karena tidak tersedia in situ. Contoh, untuk pengomposan perlu membeli minuman yakult sebagai stater pengomposan dan pembuatan bibit kompos. Disamping itu, model pengomposan Takura ini lebih sesuai untuk kompos berbahan limbah organik rumah tangga dari jenis sayuran dan sisa nasi. Oleh karena itu, untuk jenis limbah organik yang kasar, seperti limbah kulit singkong, dan bervolume besar perlu ada modifikasi model pengomposan Takakura

Modifikasi proses pengomposan terletak pada wadah pengomposan, bibit (biang) kompos yang digunakan, ketinggian timbunan kompos, dan masa pengomposan. Sementara yang tidak berubah adalah proses pengomposan Takakura yang menerapkan proses pengomposan secara aerobik. Dengan demikian, selama proses tidak timbul bau busuk, dan produk yang dihasilkan adalah kompos dengan karakteristik sebagai berikut: (1) tidak berbau, (2) remah; (3) berwarna kehitaman; (4) mengandung hara yang tersedia bagi tanaman; (5) memiliki kemampuan mengikat air tinggi.

Kegiatan pengabdian ini bertujuan (1) memberikan pengayaan pengetahuan tentang kompos, proses pengomposan dan manfaat kompos untuk peningkatan produktivitas tanaman; (2) memberikan bimtek pembuatan mikroba pengurai bahan organik MOL dan proses pengomposan limbah kulit singkong dengan metode Takakura modifikasi.

\section{Metode}

Pelaksanaan kegiatan berlangsung selama kurun waktu 6 bulan, mulai dari bulan April sampai akhir bulan Oktober 2020. Masyarakat sasaran adalah ibu rumah tangga dari kelompok yang berlokasi di Desa Narmada kecamatan Narmada Kabupaten Lombok Barat, Provinsi NTB. Kegiatan ini menerapkan pendekatan partisipatif yang mana khalayak sasaran berperan secara aktif pada setiap tahap kegiatan mulai dari tahap perencanaan, pelaksanaan, dan evaluasi kegiatan. Di kegiatan pengabdian ini ada dua bentuk kegiatan yaitu (1) penyuluhan yang bertujuan untuk meningkatkan pengetahuan khalayak sasaran tentang teori kompos, proses pengomposan, dan manfaat kompos di bidang budidaya tanaman; (2) peningkatan ketrampilan melalui praktik langsung pendampingan teknologi pembuatan kompos dengan metode Takakura modifikasi.

\section{Persiapan Kegiatan}

Diawali dengan kegiatan FGD untuk membangun kesepakatan bersama terkait dengan (1) tanggungjawab pelaksana pengabdian dan kontribusi khalayak sasaran; dalam hal ini tim pelaksana bertanggung jawab atas biaya pelaksanaan kegiatan, sedang khalayak sasaran berkontribusi pada pengadaan bahan kompos, tenaga dan tempat pengomposan; (2) penetapan jadwal dan lokasi pelaksanaan kegiatan serta topik materi penyuluhan.

\section{Pelaksanaan Kegiatan}

\section{a. Penyuluhan}

Materi penyuluhan tentang kompos, proses pengomposan dan manfaat kompos 
dalam memperbaiki produktivitas tanaman. Materi disampaikan kepada khalayak sasaran dengan metode ceramah, diskusi dan tanya jawab. Kegiatan ini bertujuan untuk memperkaya khasanah pengetahuan kelompok sasaran tentang kompos, proses pembuatan dan manfaatnya di bidang budidaya tanaman.

\section{b. Bimtek Pembuatan Kompos.}

Kegiatan bimbingan teknis pembuatan kompos meliputi bimbingan pengadaan mikroba pengurai, proses pengomposan, pemanenan kompos dan pewadahan kompos.

\section{Hasil dan Pembahasan}

\section{Kegiatan Penyuluhan}

Penyuluhan tentang kompos dan proses pengomposan dilakukan secara klasikal disampaikan dengan metode ceramah. Penyampaian materi diawali dengan penjelasan tentang pengertian kompos, kompos sebagai pupuk organic padat, prinsip dasar pengomposan. Berikut adalah cuplikan gambar pada kegiatan penyuluhan (Gambar 1).

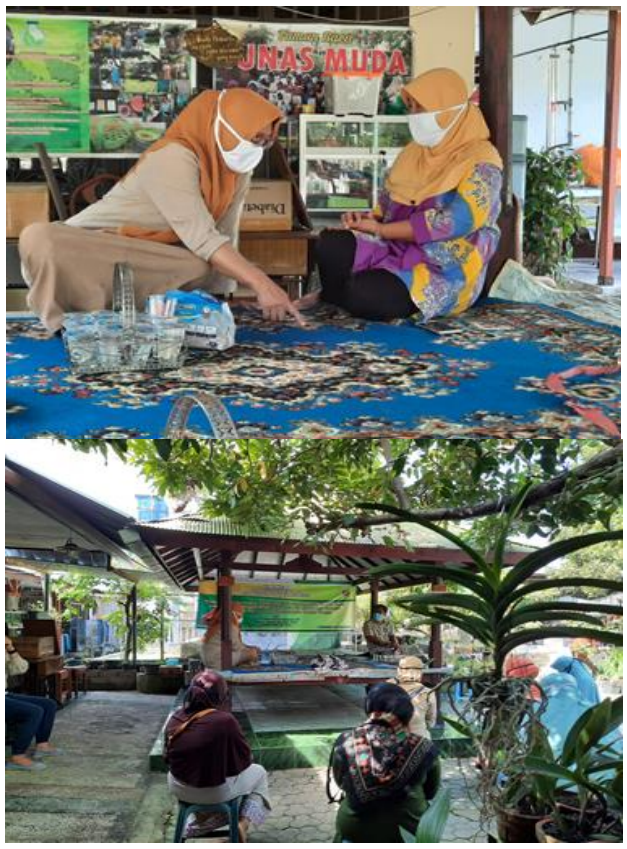

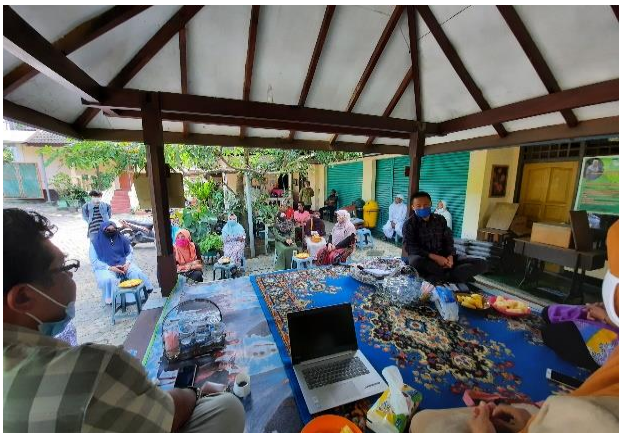

Gambar 1. Penyuluhan Tentang Kompos

Penyampaian materi pada kegiatan penyuluhan ini diawali dengan pertanyaan "apa itu kompos, bagaimana proses pembuatannya dan apa kegunaannya". Kepada khalayak sasaran diberikan pemahaman tentang definisi kompos. Kompos adalah pupuk organik yang merupakan hasil penguraian atau dekomposisi bahan organik asal limbah tanaman, kotoran hewan, dan sampah organik yang proses penguraian nya dilakukan oleh mikroorganisme aktif, seperti bakteri dan jamur (Djaja, 2008). Kemudian, dilanjutkan dengan ciriciri umum kompos yang siap diaplikasikan, adalah sebagai berikut (Setyorini \& Saraswati, 2006): (1) bau kompos sama dengan tanah, tidak berbau busuk; (2) warna kompos coklat kehitaman, berbentuk butiran gembur seperti tanah; (3) jika dimasukkan ke dalam air seluruhnya tenggelam, dan air tetap jernih tidak berubah warna, (4) jika diaplikasikan pada tanah tidak memicu tumbuhnya gulma.

Terkait dengan proses pengomposan, kepada khalayak sasaran dijelaskan prinsip pengomposan dan bagaimana menyiasati proses pengomposan dapat dipercepat, sehingga dalam waktu yang tidak lama dihasilkan produk kompos yang siap diaplikasikan. Pada prinsipnya, limbah organik segar tidak dapat langsung diaplikasikan sebagai pupuk, karena kandungan nisbah $\mathrm{C} / \mathrm{N}$ nya masih relatif tinggi, sehingga bahan organik segar harus dikomposkan terlebih untuk menurunkan nisbah $\mathrm{C} / \mathrm{N}$ pada tataran $\leq 20$. Secara alami, bahan organik dapat berubah menjadi kompos, yang prosesnya dapat berlangsung baik secara aerobik atau anaerobik.

Secara umum tahapan pengomposan dibagi menjadi tiga fase. Fase pertama merupakan dekomposisi bahan organik yang mudah terurai, menghasilkan panas yang tinggi dan berlangsung singkat. Kemudian diikuti fase kedua yaitu penguraian bahan organik yang sulit terurai. Kedua 
fase tersebut menghasilkan kompos segar. Kemudian fase ketiga berupa pematangan kompos menjadi ikatan komplek lempung-humus yang hasilnya berupa kompos matang. Cirinya, tidak berbau, remah, warna kehitaman, mengandung hara dan memiliki kemampuan mengikat air. Pengomposan dapat berlangsung secara anaerobik dan aerobik.

Reaksi pengomposan secara anaerob berlangsung dalam 4 tahap, yaitu hidrolisis, asidogenesis, asetogenesis, dan metanogenesis. Tahap pertama, beberapa jenis bakteri fakultatif akan menguraikan bahan organik menghasilkan senyawa organik sederhana (mis asam amino, gula dan asam lemak). Kemudian diikuti tahap kedua, dimana kelompok mikroba lain akan mengubah senyawa organik sederhana tersebut menjadi asam lemak yang lebih rendah (asam asetat, asam propanoat dan asam butirat), karbon dioksida dan hidrogen. Tahap keempat adalah matagonisis, pada tahap ini dihasilkan gas metana oleh bakteri metanogen. Dekomposisi sampah organik secara anaerobik terjadi tanpa adanya oksigen bebas, memanfaatkan kelompok mikroorganisme yang berbeda pada setiap tahapnya dan produk akhirnya sejumlah jenis gas dengan jenis gas dominan adalah metana $\left(\mathrm{CH}_{4}\right)$ dan karbondioksida $\left(\mathrm{CO}_{2}\right)$ (Prajapati et al., 2021)

Metode pengomposan metode Takakura pada dasarnya merupakan proses pengomposan aerobik. Pengomposan sampah organik merupakan proses penguraian bahan organik secara biologis oleh mikroba-mikroba yang memanfaatkan bahan organik sebagai sumber karbon dan energi (Sánchez et al., 2017). Proses pengomposan aerobik dicirikan oleh pelepasan panas dan gas $\mathrm{CO}_{2}$ dari bahan kompos (Simanungkalit et al., 2006) (Gambar 2). Selama proses pengomposan secara aerob tidak timbul bau busuk, karena bau yang ditimbulkan dapat dikendalikan oleh kecukupan oksigen. Kenaikan suhu akibat panas yang dilepas selama proses dekomposisi sangat menguntungkan bagi lingkungan, karena mikroorganisme patogen akan mati pada fase termofilik. Namun, apabila suhu pengomposan melebihi $65^{\circ} \mathrm{C}$ dan berlangsung relatif lama mengakibatkan proses pengomposan berjalan lambat, karena banyak mikroba pengurai yang mati. Untuk itu perlu penurunan suhu dengan cara kompos diaduk dan/atau dibalik. Percepatan pengomposan dapat dilakukan dengan pencacahan bahan, penggunaan bibit kompos dan penambahan mikroba pengurai (Susilowati et al., 2021).

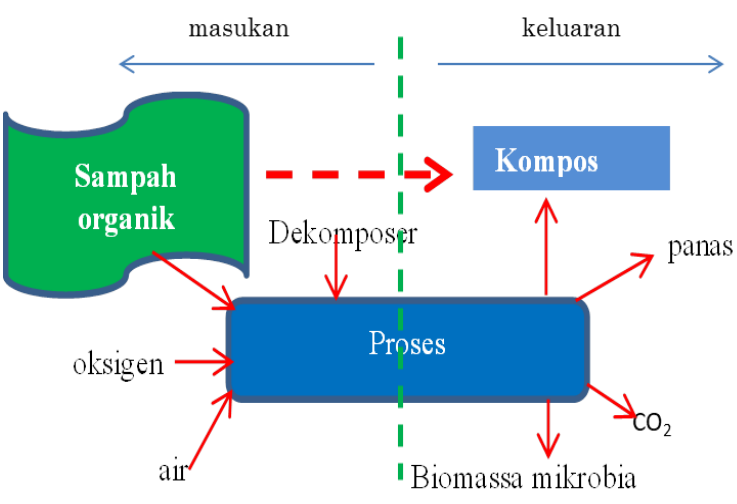

Gambar 2. Proses pengomposan secara aerobic.

Dewasa ini, terdapat banyak formula mikroba pengurai (dekomposer) bahan organik yang diproduksi secara komersial dengan berbagai merk dagang, diantaranya EM4, Promi, Orgadec, DSAplus. Mikroba pengurai dapat juga disediakan secara mandiri yang umum disebut dengan MOL (mikro organisme lokal). Proses pembuatan MOL sangat mudah, sederhana dan murah. Bahan baku MOL dapat berasal dari bongkol pisang, nasi yang rusak, limbah buah-buahan ataupun limbah organik lainnya yang mulai membusuk (Kurniawan, 2018). Penggunaan MOL sebagai dekomposer mempunyai kelebihan dan kekurangan dibanding dengan produk yang dikomersialkan. Kelebihan penggunaan MOL adalah MOL yang baru dihasilkan dan langsung digunakan dapat dipastikan bahwa mikroba larutan MOL masih hidup dan aktivitas cukup tinggi. Kelemahannya adalah ragam jenis mikroba dalam larutan MOL tidak dapat disebutkan karena tidak diidentifikasi. Selanjutnya untuk meningkatkan pengetahuan khalayak sasaran terkait dengan manfaat penggunaan pupuk kompos di bidang budidaya tanaman, diberikan materi sebagaimana yang disajikan pada Gambar 3 .

Pupuk kompos bertindak sebagai pemasok hara tanaman, sehingga mengurangi penggunaan pupuk mineral. Pupuk kompos mempunyai kemampuan mengikat air sehingga kelembaban tanah terjaga dalam waktu yang lebih lama. Dengan kata lain, kompos meningkatkan kemampuan tanah untuk menyimpan air sehingga terjadi efisiensi pengairan. Kompos juga membuat tanah menjadi gembur dan cocok sebagai media tumbuh akar tanaman. Pada tanah tipe pasir sekalipun, material kompos berguna menjadi perekat sehingga tanah menjadi lebih solid. Sedangkan pada tanah liat atau 
tanah lempung, kompos berfungsi menggemburkan tanah agar tidak terlalu solid. Secara kimiawi, pupuk kompos bisa meningkatkan kapasitas tukar kation dalam tanah. Secara biologi, pupuk kompos adalah media yang baik bagi kehidupan dan aktivitas organisme pemasok dan pendaur hara penting bagi tanaman (Martínez-Blanco et al., 2013).

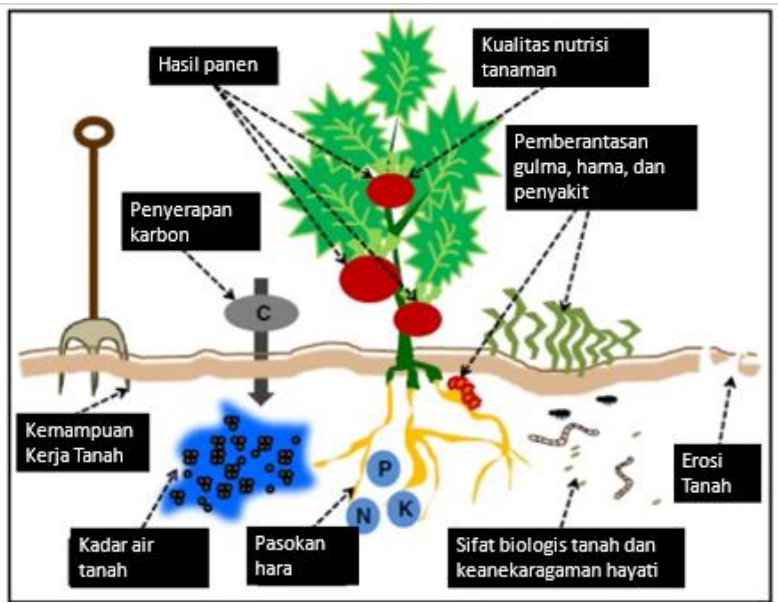

Gambar 3. Manfaat pupuk kompos untuk kesuburan tanah, pertumbuhan dan hasil tanaman (Martínez-

Blanco et al., 2013).

Dari aspek ekonomi mengolah limbah kulit singkong menjadi kompos dapat menjadikan alternatif usaha sebagai sumber pendapatan, disamping juga ikut berkontribusi dalam menjaga lingkungan bersih dan sehat. Pupuk kompos memiliki nilai jual yang lebih tinggi daripada limbah kulit singkong. Dari aspek lingkungan, mengolah kulit singkong menjadi kompos dapat 1) mengurangi polusi udara karena pembakaran limbah dan pelepasan gas metana yang terlepas dari timbunan kulit singkong yang membusuk secara anaerobik; 2) mengurangi kebutuhan lahan untuk penimbunan limbah kulit singkong. Dari aspek budidaya tanaman, kompos limbah kulit singkong merupakan pupuk organik yang bermanfaat untuk meningkatkan produktivitas tanaman.

\section{Bimtek Pembuatan Kompos Metode Takakura Modifikasi}

\section{a. Pembuatan bibit kompos MOL}

Peserta melakukan praktek langsung pembuatan bibit kompos dibawah bimbingan nara sumber. Bibit kompos dibuat ari bonggol pisang yang difermentasi. Sebagai sumber karbon dan energy untuk pembiakan mikroba dalam larutan fermentasi campuran air kelapa, air cucian beras dan gula merah. Bibit kompos dapat dibuat dari berbagai limbah organik yang telah mengalami pembusukan dan difermentasi pada suatu medium buatan yang mengandung karbohidrat sebagai sumber nutrisi mikroba dalam larutan MOL (Cybext, 2019). Komposisi bibit kompos dari bonggol pisang adalah sebagai berikut (a) $5 \mathrm{~kg}$ bonggol pisang; (b) 2,5 L air cucian beras dicampur dengan 2,5 L air kelapa dan (c) 0,25 kg gula jawa.

Tahap pembuatan bibit kompos sebagai berikut. Pertama, Bonggol pisang dipotong-potong, kemudian dimasukan ke dalam ember sambil dilumatkan. Kedua, dibuat larutan dengan komposisi air kelapa air, cucian beras dengan perbandingan 1 : 1 bagian dan ditambah gula kelapa yang sudah dihaluskan sebanyak $2 \%$ dari berat larutan. Ketiga, larutan yang telah dipersiapkan dituang ke dalam toples yang berisi potongan bonggol pisang hingga ketinggian $2 / 3$ toples kaca, kemudian diaduk sampai merata. Selanjutnya toples ditutup rapat dan diberi lubang pernafasan satu arah dengan cara melubangi tutup toples dan dipasang selang yang ujung selang dimasukkan ke dalam botol berisi air. Hal ini dimaksudkan untuk mengeluarkan gas yang ada di dalam toples dan menghambat masuknya gas luar ke dalam toples (Gambar 5, sisi tengah). Suspensi MOL diperam selama tiga minggu. Ciri bibit kompos yang siap dipanen sebagai berikut: 1) larutan berbau seperti alkohol, terbentuk miselium, dan 2) warna larutan lebih jernih dibandingkan dengan saat awal pembuatan.
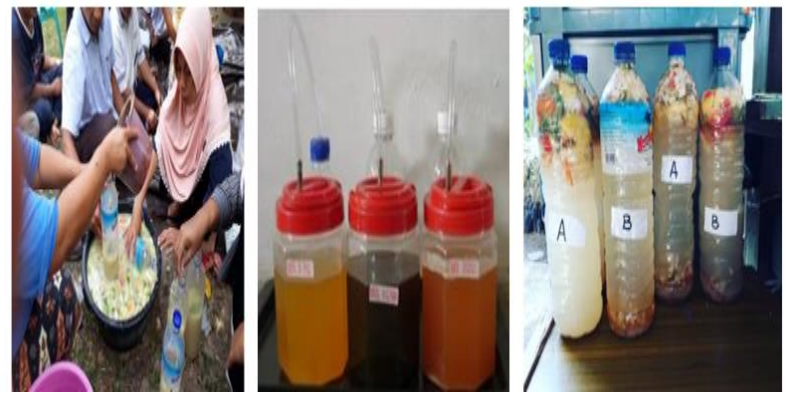

Gambar 4. Pembuatan Bibit Kompos.

Mikroba yang berkembang dalam larutan fermentasi MOL dapat dimanfaatkan sebagai bibit kompos pada proses pengomposan ataupun digunakan langsung sebagai pupuk hayati cair. Penggunaan larutan sebagai bibit kompos dalam proses pengomposan diberikan dengan mencampur 1-liter bibit kompos dengan 10-liter air kemudian 
ditambahkan 2 ons gula merah. Bibit kompos sebagai penyubur tanaman, dapat diaplikasikan langsung ke tanaman dengan mencampurkan $10 \mathrm{ml}$ larutan dengan 1 liter air bersih. Aplikasi pada tanaman dilakukan dengan menyemprotkan campuran larutan tersebut setiap 10 hari sekali selama fase vegetatif. Umumnya suatu bibit kompos tidak hanya mengandung 1 jenis mikroorganisme tetapi beberapa mikroorganisme pemacu partumbuhan tanaman seperti Pseudomonas sp., Aspergillus dan Bacillus sp.

\section{Bimtek Pembuatan Kompos Metode Takakura Modifikasi}

Metode pengomposan Takakura menerapkan proses pengomposan aerobik dipercepat. Metode ini dikenalkan oleh Koji Takakura, peneliti asal Jepang, dan mulai dikenalkan di masyarakat sejak tahun 2004. Pengomposan dilakukan di keranjang kompos berlubang yang dilapisi kardus untuk menjaga sirkulasi udara dan kelembaban selama proses pengomposan. Sebagai biang kompos digunakan kompos setengah jadi yang mengandung mikroba. Metode pengomposan Takakura ini sesuai untuk pengolahan kompos berbahan baku lunak (seperti sayuran, limbah nasi) dan untuk skala rumah tangga (Nurdini et al., 2016). Kapasitas keranjang Takakura sekitar 1,5 per bahan kompos dengan masa pengomposan \pm 10 hari.

Terkait dengan pengolahan limbah organik dengan karakteristik agak kasar (limbah kulit singkong) perlu dilakukan modifikasi teknik pengomposan turunan metode Takakura. Modifikasi terletak pada bibit (biang) kompos yang digunakan, ketinggian timbunan kompos, wadah pengomposan dan masa pengomposan. Pergeseran modifikasi sistem pengomposan metode Takakura disajikan dalam Tabel 1.

Tabel 1. Perbandingan Sistem Takakura dan Takakura modifikasi

\begin{tabular}{|l|l|}
\hline \multicolumn{1}{|c|}{ Sistem Takakura } & \multicolumn{1}{|c|}{ Sistem Takakura modifikasi } \\
\hline Proses pengomposan aerobik & Proses pengomposan aerobik \\
\hline Produksi kompos skala rumah tangga & Produksi kompos untuk usaha \\
\hline $\begin{array}{l}\text { Bibit (biang) kompos bersumber: kompos setengah jadi } \\
\text { yang mengandung mikroba pengurai }\end{array}$ & $\begin{array}{l}\text { Bibit (biang) kompos bersumber: pupuk kandang yang } \\
\text { diperkaya dengan MOL plus dedak }\end{array}$ \\
\hline $\begin{array}{l}\text { Bahan yang kompos: bahan dengan tekstur relatif lunak } \\
\text { (sisa nasi dan sayur) }\end{array}$ & $\begin{array}{l}\text { Bahan yang kompos: bahan dengan tekstur agak keras } \\
\text { (kulit singkong) }\end{array}$ \\
\hline $\begin{array}{l}\text { Timbunan bahan kompos, dari bawah ke atas: (1) } \\
\text { bantalan sekam padi, (2) bibit kompos setinggi 5 cm di } \\
\text { atas permukaan bantalan alas, (3) limbah sayuran yang } \\
\text { mengandung mikrobia (setinggi 5 cm, boleh di atasnya } \\
\text { ditaburi dedak/bekatul). Untuk bagian lapisan atasnya } \\
\text { mengikuti urutan susunan lapisan pengomposan }\end{array}$ & $\begin{array}{l}\text { Timbunan bahan kompos, dari bawah ke atas: (1) } \\
\text { sekam padi (5 cm), (2) bibit kompos setinggi 7,5 cm di } \\
\text { Takakura tersebut yang dimulai dari bantalan sekam } \\
\text { setinggi 7,5 cm, semprot MOL dan taburi } \\
\text { dedak/bekatul secukupnya. Ketinggian lapisan } \\
\text { timbunan kompos sekitar 20 - 25 cm, kemudian } \\
\text { diulang dengan urutan lapisan yang sama di bagian } \\
\text { atasnya, dimulai dari sekam padi. }\end{array}$ \\
\hline $\begin{array}{l}\text { Wadah pengomposan: keranjang kompos; keranjang } \\
\text { kompos diisi timbunan kompos hingga mencapai 2/3 dari } \\
\text { ketinggian keranjang kompos }\end{array}$ & $\begin{array}{l}\text { Wadah pengomposan: bak kompos; bak kompos diisi } \\
\text { timbunan kompos hingga mencapai 2/3 dari ketinggian } \\
\text { bak kompos }\end{array}$ \\
\hline Kelembaban proses pengomposan 60\% dari berat & Kelembaban proses pengomposan 60\% dari berat \\
\hline Masa pengomposan: 2 minggu, kompos jadi & Masa pengomposan: 3-4 minggu, kompos jadi \\
\hline
\end{tabular}

Pada prinsipnya proses pembuatan kompos berbahan limbah organik rumah tangga atau limbah industri pangan skala rumah tangga dapat dikerjakan secara mandiri oleh anggota keluarga sendiri, di lingkungan rumah tangga sendiri, atau secara berkelompok. Pada prakteknya untuk mengolah sampah menjadi barang berkah dibutuhkan kemauan dan ketekunan dari anggota keluarga. Dalam hal ini, peran ibu rumah tangga sebagai motivator dan sekaligus pelopor kegiatan pengolahan limbah organik menjadi penting kehadirannya. Beberapa gambar cuplikan kegiatan proses pembuatan kompos disajikan pada Gambar 5 . 


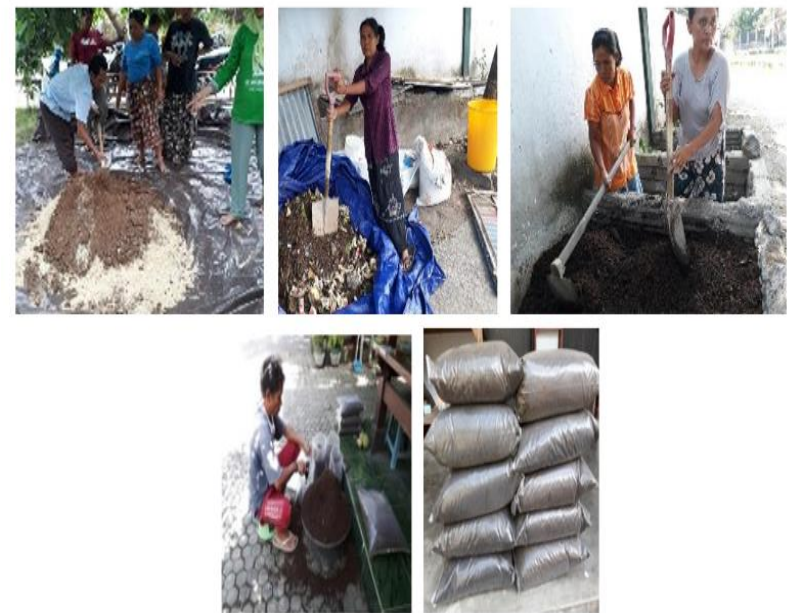

Gambar 5. (a) mencampur pupuk kandang plus MOL plus dedak; (b) Limbah kulit singkong; (c) Pengadukan kompos di bak kompos; (d) Pewadahan kompos; (e) kompos siap jual.

\section{Evaluasi Pelaksanaan Kegiatan}

Hasil evaluasi terhadap ketercapaian tujuan kegiatan dapat dikemukakan sebagai berikut. Dalam ranah kognitif (pengetahuan) mitra penerima manfaat memperlihatkan adanya peningkatan pengetahuan tentang kompos dan teknik pembuatannya. Sebagai indikatornya adalah $70 \%$ dari peserta penyuluhan menjadi tahu dan mengerti bahwa ada teknik pengomposan secara cepat dan tidak memunculkan bau yang tidak sedap. Khalayak sasaran semakin memahami dan mengerti strategi mengolah limbah organik melalui daur ulang sampah menjadi kompos dapat mengubah sampah menjadi sesuatu produk yang bernilai ekonomi. Khalayak sasaran juga semakin paham bahwa melakukan pengelolaan sampah secara mandiri merupakan keniscayaan dalam menjaga kebersihan dan kesehatan minimal untuk lingkungan masing-masing rumah tangga.

Khalayak sasaran memberikan respon positif terhadap materi pelatihan pembuatan dekomposer lokal. Hal ini ditunjukkan dengan peserta menerima dan mengadopsi teknologi tersebut. Ketertarikan peserta terhadap teknologi pembuatan dekomposer lokal cukup tinggi dengan alasan sebagai berikut: teknologinya mudah, murah, dan bahan yang dihasilkan mempunyai manfaat yang besar. Proses pengomposan dengan aplikasi dekomposer lokal dapat mempercepat waktu pengomposan dengan kualitas kompos memenuhi SNI 19-7030-2004 tentang "Spesifikasi Kompos dari Sampah Organik Domestik"

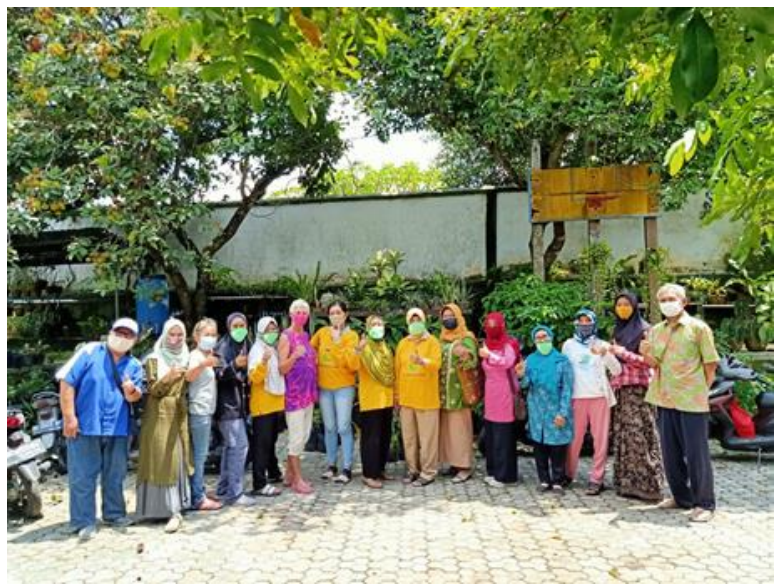

Gambar 6. Foto bersama di akhir kegiatan pengabdian

\section{Kesimpulan}

Kegiatan pengabdian ini mendapat respon positif dan terjadi kerjasama yang baik antara khalayak sasaran dan pelaksana pengabdian. Dari kegiatan penyuluhan, khalayak sasaran mendapatkan ilmu pengetahuan tentang kompos, teknik pembuatan kompos dan manfaat kompos di bidang budidaya tanaman. Dari kegiatan bimtek pembuatan kompos, khalayak sasaran termotivasi untuk mengolah limbah kulit singkong menjadi kompos untuk menyuburkan tanah. Khalayak sasaran telah memperoleh pembelajaran teknis membuat MOL dari bonggol pisang.

\section{Ucapan Terima Kasih}

Ucapan terimakasih disampaikan kepada Rektor Universitas Mataram, Ketua LPPM Universitas Mataram dan Dekan Fakultas Pertanian Universitas Mataram yang telah mengijinkan dan membiayai kegiatan pengabdian ini dengan sumber dana PNBP Tahun Anggaran 2020. Terima kasih juga disampaikan kelompok PaManSam sebagai mitra PKM atas kerjasama yang baik, sehingga kegiatan berjalan lancar dan bermanfaat. Kepada mahasiswa yang terlibat dalam PKM ini kami juga menyampaikan terimakasih.

\section{Daftar Pustaka}

Bui, T.-A., Pham, V.-H., Nguyen, H.-B., Nguyen, T.-P., \& Nguyen, D.-K. (2018). Study of Using Cassava Pulp to Produce Livestock Feed Pellet. 
Int. J. Adv. Sci. Eng. Inf. Technol, 8(1), 242249.

Cybext. (2019). Cara Membuat Mikro Organisme Lokal (MOL).

Http://Cybex.Pertanian.Go.Id/Mobile/Artikel/83 580/Cara-Membuat-Mikro-Organisme-LokalMOL/.

Djaja, W. (2008). Langkah jitu membuat kompos dari kotoran ternak \& sampah. AgroMedia.

Elemike, E. E., Oseghale, O. C., \& Okoye, A. C. (2015). Utilization of cellulosic cassava waste for bioethanol production. Journal of Environmental Chemical Engineering, 3(4), 2797-2800.

Fadli, C. M. S. K. R. (2020). ANALISIS RASIO C/N KOMPOS LIMBAH KULIT UBI AKIBAT PENGECILAN UKURAN BAHAN DAN LAMA FERMENTASI. Jurnal Sains Riset, 9(3), 22-27.

Fitriani, H., \& Ciptandi, F. (2017). Pengolahan Kulit Umbi Singkong (Manihot Utilissima) di Kawasan Kampung Adat Cireundeu Sebagai Bahan Baku Alternatif Perintang Warna Pada Kain. EProceedings of Art \& Design, 4(3).

Kurniawan, A. (2018). Produksi Mol (Mikroorganisme Lokal) dengan Pemanfaatan Bahan-Bahan Organik yang Ada di Sekitar. Jurnal Hexagro, 2(2).

Martínez-Blanco, J., Lazcano, C., Christensen, T. H., Muñoz, P., Rieradevall, J., Møller, J., Antón, A., \& Boldrin, A. (2013). Compost benefits for agriculture evaluated by life cycle assessment. A review. Agronomy for Sustainable Development, 33(4), 721-732.

Nurdini, L., Amanah, R. D., \& Utami, A. N. (2016). Pengolahan limbah sayur kol menjadi pupuk kompos dengan metode Takakura. Seminar Nasional Teknik Kimia Kejuangan, 2.

Obueh, H. O., \& Odesiri-Eruteyan, E. (2016). A study on the effects of cassava processing wastes on the soil environment of a local cassava mill. $J$ Pollut Eff Cont, 4(4).

Oghenejoboh, K. M., Orugba, H. O., Oghenejoboh, U. M., \& Agarry, S. E. (2021). Value added cassava waste management and environmental sustainability in Nigeria: a review. Environmental Challenges, 4, 100127.

Prajapati, P., Varjani, S., Singhania, R. R., Patel, A. K., Awasthi, M. K., Sindhu, R., Zhang, Z., Binod, P., Awasthi, S. K., \& Chaturvedi, P. (2021). Critical review on technological advancements for effective waste management of municipal solid waste-Updates and way forward. Environmental Technology \& Innovation, 23, 101749.

Sánchez, Ó. J., Ospina, D. A., \& Montoya, S. (2017). Compost supplementation with nutrients and microorganisms in composting process. Waste Management, 69, 136-153. https://doi.org/https://doi.org/10.1016/j.wasman .2017.08.012

Setyorini D., Saraswati R., A. E. (2006). . (2006). Kompos. Balai Besar Litbang Sumberdaya Lahan Pertanian Badan Penelitian dan Pengembangan Pertanian. In Pupuk Organik dan Pupuk Hayati. Editor: RDM Simanungkalit., Didi Ardi Suridikarta., Rasti Saraswati, Diah Setyorini dan Wiwik Hartatik.

Susilowati, L. E., Arifin, Z., \& Kusumo, B. H. (2021). PENGOMPOSAN SAMPAH ORGANIK RUMAH TANGGA DENGAN DEKOMPOSER LOKAL DI DESA NARMADA, KABUPATEN LOMBOK BARAT. JMM (Jurnal Masyarakat Mandiri), 5(1), 34-45. 